\title{
Nelegālā migrācija drošības nodrošināšanas kontekstā
}

\author{
Dr. iur. Andrejs Vilks \\ Rīgas Stradiña universitāte, Juridiskā fakultāte, \\ Tiesību zinātñu katedra, Latvija \\ Andrejs.Vilks@rsu.lv
}

\section{Kopsavilkums}

Sociāli politiskā un ekonomiskā situācija migrantu izcelsmes valstīs ir izteikti nelabvēlīga, un tas ietekmē nekontrolējamu bēgḷu un migrantu pieplūdumu Eiropas Savienības valstīs. ES ārējās robežas nav pietiekami nostiprinātas un drošas. Bēgḷu un migrantu izvietošanas punkti lielākoties nav nodrošināti ar nepieciešamajiem resursiem sociālās palīdzības sniegšanā. Migrantu vēlmes kḷūt materiāli nodrošinātiem, pilnīgi neatkarīgiem jaunajās, drošajās trešajās valstīs netiek piepildītas. Tas determinē sociālās spriedzes eskalāciju, konfliktu veidošanos starp patvēruma meklētājiem un trešo (Eiropas) valstu iedzīvotājiem. Konflikti pāraug sabiedriskās kārtības pārkāpumos un krimināla rakstura aktivitātēs. Samazinās nacionālā un starptautiskā drošība, kas ir saistīta ar strauju migrantu pieplūdumu Eiropā.

Atslēgvārdi: drošība, globalizācija, migrācija, nelegālā migrācija.

Augsts migrācijas līmenis ir ierasta mūsdienu civilizācijas iezīme. Gandrīz visas pasaules valstis ir iesaistìtas migrācijas procesos. Katru gadu miljoniem cilvēku visā pasaulē šķērso valstu robežas, lai iegūtu atbilstošu darbu ar labāku atalgojumu, piedalītos izglìtības programmās, atpūstos, sazinātos ar radiniekiem un citiem tuviem cilvēkiem vai arī izvairìtos no kriminālvajāšanas un sodu izpildes. Jāuzsver, ka piespiedu migrācija var būt saistīta ar militāriem konfliktiem, karadarbību un ekstremālām situācijām (dabas katastrofām, politiskā režīma maiṇu). Migrācijas procesu analīze var liecināt par neapmierinošiem sociāliem, tiesiskiem un politiskiem apstākḷiem konkrētā valstī, ekonomikas attīstības līmeni, cilvēku drošības stāvokli konkrētā pasaules reǵionā. Migrācijas tendences ir saistītas ar atšḳirīgiem sadzīves apstākḷiem un dzìves līmeni, kā arī nelabvēlīgiem vides faktoriem. 
Ekonomikas zinātṇu doktors I. Brīvers atzīst, ka migrācija ir globalizācijas sekas un tas ir ilgstošs process. Tas ir skāris arī Latviju. Pēc viṇa domām, "ikviens, kurš aizbrauc, aizved no Latvijas vismaz 20 tūkstošus eiro. Tas ir naudas daudzums, kuru Latvija iztērēja, lai šos cilvēkus izaudzinātu un lai viṇi sasniegtu noteiktu izglìtības līmeni, tās ir Latvijas izmaksas, lai cilvēku sagatavotu darba tirgum" (Ivars Brīvers, 2016). Tomēr sakarā ar to, ka Latvijā nav nepieciešamo dzīves apstākḷu, valsts iedzivotāji ir spiesti emigrēt.

Aplūkojot migrācijas problēmu kopumā, ir jāatzīst, ka īpaši nelabvēlīga, ar grūti analizējamu procesu un nenosakāmām sekām ir nelegālā, nereǵistrētā un neoficiālā migrācija, kura netiek ietverta nevienā atskaites formā un apkopojumā.

Analizējot nelegālās migrācijas stāvokli, tendences un perspektīvas, pētnieki galvenokārt balstās uz apsekojumu rezultātiem un ekspertu vērtējumiem. Tomēr tie ir visai nosacīti un aptuveni. Bez šaubām, ir jāatzīst, ka šie vērtējumi l̦auj apzināt nelegālo migrantu stāvokli un plūsmu, kā arī tie ir migrācijas drošības pasākumu izstrādes pamats. Migrācijas drošîbu mēs saprotam kā sabiedriskās (sociālās, ekonomiskās, tiesiskās) un nacionālās (arī globālā kontekstā) sistēmas stāvokli, kurā netiek apdraudēta cilvēku dzīvība, veselība, gods, brīvības, īpašums un citas vērtības, kuras ir saistītas ar iedzīvotāju kontrolētu vai nelegālu pārvietošanos valsts vai transnacionālos ietvaros. Lat vijas nacionālajā attīstības plānā ir ietverta arī visai specifiska kategorija - drošumspēja (Cilvēka drošumspēja un NAP2020).

Aplūkotajā tematā mēs varam iekḷaut arī migrācijas drošumspēju kā cilvēku spējas un sabiedrības stāvokli (potenciālu) nenonākt apdraudētās situācijās un nezaudēt drošības sajūtu, kura ir saistîta ar migrācijas procesiem. Jāuzsver, ka ir iespējams diferencēt iedzīvotāju iekšējo pārvietošanos (vietējo migrāciju) un starpvalstu pārvietošanos (ārējo migrāciju). Raksta autors pievērsīsies galvenokārt tikai ārējās un nelegālās migrācijas tendenču un izpausmju analīzei.

Atbilstoši Starptautiskās darba organizācijas datiem nelegālie imigranti veido 10-15\% no kopējās migrācijas plūsmas apjoma (Rukovodstvo, 2006, 185). Neapšaubāmi, tas ir pietiekami augsts īpatsvars un var būtiski ietekmēt to valstu sociālo, ekonomisko un politisko stāvokli, kuras uzṇem migrantus. Augsta nelegālā migrācija ir vērojama no jaunattīstības valstīm uz valstīm ar augstu attīstības un dzìves līmeni. Pētỉjums, kuru ir veikusi "Pew Research", liecina, ka lielākais skaits imigrantu dzīvo ASV aptuveni 46 miljoni cilvēku (Connor, Cohn E Gonzalez-Barrera, 2006). Saskan̄ā ar Eiropas Universitātes institūta pētījumu ES valstīs ir aptuveni 43 miljoni viesstrādnieku, no kuriem 23 miljoni ir personas, kuras ir iebraukušas no citām valstīm. Pēc ekspertu atzinumiem patlaban ES valstīs ir aptuveni 6-10 miljoni nelegālo migrantu (Migration Reports, 2013).

Savukārt citu pētījumu rezultāti liecina, ka nelegālo migrantu skaits it krietni lielāks. Tiek atzīts, ka pašlaik ES valstīs ir vairāk nekā 33,5 miljoni migrantu (Migration and migrant population statistics, 2015). Lielākā daḷa migrantu ir izceḷotāji no Ziemeḷāfrikas un Āzijas valstīm. Izplatītākie nelegālo migrantu ieceḷošanas maršruti ir Rietumbalkānu un Vidusjūras austrumu regioni (Grieḳija, Turcija). Situācija nelegālās migrācijas 
jomā kopumā negatīvi ietekmē sabiedrisko drošību un arī dažu valstu nacionālo drošību. Eksperti uzskata, ka nelegālās migrācijas plūdi, kas līdztekus nes arī pieaugošo terorismu, ir neadekvātas ES migrācijas politikas sekas. Konsekventas migrācijas politikas trūkums nākotnē Eiropas valstīs var izraisìt vēl nelabvēlīgāku un kriminogēnāku situāciju.

Nelegālā migrācija pēc savas būtības ir nelikumīga cilvēku pārvietošanās pāri valstu robežām, pārkāpjot valsts noteikto ieceḷošanas, tranzìta, uzturēšanās un izceḷošanas kārtību ārvalstu pilsoṇiem un bezvalstniekiem.

Nelegālo migrāciju atkarībā no dažādiem faktoriem var iedalīt šādi:

- atkarībā no organizētības pakāpes - organizētā un neorganizētā migrācija;

- atkarībā no nelegālo migrantu aptvēruma - individuālā un grupveida migrācija;

- atkarībā no valstĩ iekḷuššanas paṇēmieniem - nelikumīga robežas šḳērsošana ar viltotiem dokumentiem, izmantojot nekontrolējamu robežu, ārpus kontrolpunktiem, uzturēšanās valstī pēc aț̣autā uzturēšanās perioda.

Augstais nelegālās migrācijas līmenis, kas ES aizvien pieaug, izraisa šajās valstīs virkni problēmu, jo rada negatīvas sekas un draudus sabiedrībai un cilvēkdrošībai. No kriminologiskā aspekta pieaugs sabiedrības kriminalizācijas līmenis. Nelegālie migranti ir "trešās valsts piederīgie, kuri ir pārkāpuši iecelıošanas vai uzturēšanās nosacỉjumus Latvijas Republikā - izmantojuši viltotus dokumentus vai snieguši nepatiesu informāciju, pārsnieguši uzturēšanās laiku vai pārkāpuši darba aț̣aujas nosacỉjumus, saṇēmuši atteikumu piešḳirt tiesisko statusu Latvijas Republikā" (Latvijas praktiskā rīcība nelegālās migrācijas mazināšanai: Pētījums, 2011).

Pretēji noteiktajai tiesiskajai kārtībai valstī uzturas nereǵistrēti cilvēki, kuru vidū ir personas, kas izvairās no atbildības par prettiesiska rakstura nodarỉjumiem, organizēto kriminālo grupu pārstāvji, teroristi. Nelegālie migranti daudzos gadījumos ir iesaistīti cilvēku un ieroču tirdzniecībā, narkobiznesā, akcīzes preču kontrabandā u. c. Daḷa nelegālo migrantu neoficiāli iesaistās darba tirgū, strādājot bez atbilstošām aț̣aujām un neregistrēti. Tas sekmē ēnu ekonomikas pieaugumu un korupcijas palielināšanos.

Serbijas politologs Miḷenko Nedel̨kovskis (Миленко Неделковски) uzskata, ka ir ḷoti aizdomīgi un nesaprotami, kāpēc $90 \%$ migrantu, kuri ieceḷo Eiropā, tostarp Maḳedonijā un Serbijā, ir jauni vīrieši (Nedelkovski, 2015). Neizpratni raisa tas, ka imigranti nāk no valstīm, kur to tradicionālā kultūra nepiel̦auj un neatbalsta gimeņu sairšanu un gimenes pamešanu. M. Nedel̦kovskis kā piemēru min Maḳedoniju, kurā pēc kara ar Serbiju ieceloja aptuveni 150 tūkstoši albāṇu, kuri būtiski mainīja valsts etnisko struktūru un kultūras tradīcijas. Liels jaunu vīriešu skaits raisa pamatotas aizdomas, ka viṇu iecel̦ošanas mērḳi var būt ekstrēmistisku un agresīva rakstura darbību veikšana.

Kā piemēru var minēt notikumus Jaungada naktī Ķelnē, kad aptuveni tūkstotis jaunu vīriešu, kuri bijuši apreibinošu vielu ietekmē, sarīkoja savdabīgus izklaides pasākumus pie pilsētas centrālās stacijas. Tika saṇemts vairāk nekā 100 sūdzību no sievietēm, kuras ir cietušas no seksuālas vardarbības. No šīm sūdzībām divas bijušas par izvarošanu, bet trīs ceturtdaḷas par seksuāla rakstura uzbrukumiem. Vīrieši pēc ārējām pazīmēm bija Tuvo Austrumu un Ziemeḷāfrikas izcelsmes. Turklāt sievietes tikušas 
arī aplaupītas un apzagtas, pret viņām ir veiktas netiklas darbības. Šādi incidenti bijuši arī Hamburgā un Štutgartē. Lìdzīgi gadījumi notikuši 12 Vācijas federālajās zemēs (pavisam Vācijā ir 16 federālās zemes). Analogiski uzbrukumi ir tikuši veikti Zviedrijā, Somijā un Šveicē. Aizdomas par viltotiem dokumentiem raisa arī tas, ka Serbijas robežsardzei 90\% imigrantu uzrāda kā dzimšanas datumu viena un tā paša gada 1. janvāri. Jāpiebilst, ka nav datubāzu, uz kurām balstoties varētu veikt ieceḷojošo personu identitātes pārbaudi.

Nelegālās migrācijas problēmu lokā nelegālās migrācijas organizēšanai ir viena no būtiskākajām nozīmēm. Migrantu kontrabanda ir organizēta personu pārvietošana, atvieglojot viṇu pārvietošanos pāri robežām, pārkāpjot noteiktos tiesību aktus, lai iegūtu finansiālu vai citu labumu no personām un organizācijām, kas iesaistìtas migrantu kontrabandā (sk. Apvienoto Nāciju Organizācijas Konvencija). Lielākais apdraudējums nāk nevis no darba n̦ēmēja migranta, kurš ir kḷuvis par objektu cilvēku kontrabandā, bet gan no organizētās noziedzỉbas sindikāta, kas nodrošina bēgḷu nelegālu pārvietošanos un sañem no viņiem lielas naudas summas. Migrantu kontrabanda ir starptautiska organizēta noziedzīga parādība ar augstu peḷnu un zemu risku.

Eksperti atzīst, ka nelegālās migrācijas organizēšana nes lielāku peḷnu nekā narkotiku tirdzniecība. Ir izpētīts, ka vieta patvēruma meklētāju laivā maksā divus līdz desmit tūkstošus dolāru, no kuriem 55 procentus saṇem nelegālās migrācijas organizētāji (Ilmārs Latkovskis, 2016).

ES valstīm ir ārējās robežas ar 21 valsti. No tām aptuveni divās trešdaḷās veidojas riska situācijas, kas nosaka iespējas organizēt caur šìm valstīm kontrabandas preču pārvešanu, narkotisko vielu tranzìtu, kā arī nodrošināt nelegālo migrantu ieplūšanu ES. ES valstīm sakarā ar to, ka Savienības valstu iekšējās robežas netiek kontrolētas, imigrācijas kanālu un plūsmu apzināšanai ir ḷoti būtiska nozīme. Kaut gan ES kopumā, kā arī tās dalībvalstis cenšas kontrolēt, fiksēt un pat ierobežot migrāciju, it īpaši nelegālo, tomēr jāatzīst, ka ir vērojama izteikta migrācijas krīze. Lìdzịgas izpausmes un aptvērums bija vērojams tikai pēc Otrā pasaules kara. Tomēr patlaban situācija migrācijā nav salīdzināma ar iepriekšējām. Demogrāfijas procesu pētnieks Hansens atzīst, ka tagad migrāciju var salīdzināt ar pašregulējamu piedāvājuma un priekšlikuma tirgu (Hansen, 2002, 583).

Nelegālā migrācija ir ne tikai drauds Eiropas Savienības drošībai kopumā, bet arī atsevišķām tajā ietilpstošajām valstīm. Būtiskākie nelegālās migrācijas draudi ir šādi:

- sabiedrības un valsts sociālā, teritoriālā un demogrāfiskā stāvokḷa deformācija;

- konkurence darba tirgū un cilvēku nodrošināšanā ar nepieciešamajiem dzīves apstākḷiem, tās saasināšanās;

- etnisko, relig̣isko (konfesionālo) un kultūras vērtību, uzvedības stereotipu un normu sadursme;

- atsevišķu reǵionu un jomu kriminalizācija;

- ekstrēmisma un ksenofobijas izpausmju pieaugums. 
Nelegālo migrantu pārvietošana pāri valstu robežām ir viens no lielākajiem ienākumu avotiem organizētajiem transnacionālajiem grupējumiem. Pirmkārt, atzīmēsim, ka pašreizējā geopolitiskā situācija, konflikti un karadarbība Sīrijā, sociālā un ekonomiskā krīze Afganistānā un Irākā ir izteikti labvēlīgs apstāklis ne tikai migrācijas procesu eskalācijai, bet arī starptautisku kriminālo grupējumu izveidei, lai pārvietotu bēgḷus pāri robežām. Otrkārt, nozīmīga ir šo grupējumu komplicētā darbība, kurai ir daudz dažādu darbības virzienu. Grupējumu pārstāvju darbība sākās ar mērḳtiecīgu informācijas novadīšanu potenciālajiem migrantiem par ḷoti labvēlīgajiem apstākḷiem jaunajās mītnes zemēs Eiropā (migranti būs nodrošināti ar augstiem pabalstiem, kas novērsīs nepiecieša mību strādāt, vinu rīcībā būs ekskluzīvas mājas un dzīvokḷi, automašīnas u. c.). Minētie dzìves apstākḷi, salīdzinot ar mītnes zemē esošajiem, neapšaubāmi, izklausās pasakaini.

Savervētie migranti tika nodrošināti ar pavadoṇiem, glābšanas vestēm, laivām un informāciju par mītni jaunajās patvēruma valstīs. Pēdējos gados Vācijā ikmēneša pabalsts personai, kura iesniedza pieteikumu par viṇas atzī̌sanu par bēgli, bija 670 EUR. Ja vēlāk iesniedzējam tika pieškirirts bēgḷa statuss, tad pabalsts jau bija vairāk nekā 1000 EUR. Turklāt bēgḷa statusa ieguvējam tika piešḳirts bezmaksas dzīvoklis un nodrošināts cits sociālais atbalsts (medicīniskie pakalpojumi, izglīīiba u. c.). Šãdi pievilcīgi sociālie apstākḷi motivēja iekḷūt attīstītajās Eiropas valstīs ne tikai cilvēkus no militārajā konfliktā iesaistītajām valstīm, bet arī no Eiropas valstīm (Kosovas, Maḳedonijas, Serbijas u. c.). Var secināt, ka virknē Eiropas Savienības valstu ir izteikti labvēlīga migrācijas politika (Francijā, Beḷgijā, Nīderlandē, Lielbritānijā, Zviedrijā). Imigrantiem ir radītas iespējas dzīvot nestrādājot. Ja, piemēram, ASV jau pirmajā uzturēšanās gadā valstī ir nodarbināti 94-97\% imigrantu (bezdarbs ir 4-7\%), tad terorisma plosītajās Beḷgijā un Francijā bezdarba līmenis imigrantu vidū sasniedz 35-50\%. Šie imigranti var būt apmierināti ar savu dzīves kvalitātes līmeni, bet to nevar saprast un nesaprot imigrantu bērni, kuri ir izstumti no tradicionālās Rietumu sabiedrības.

Turklāt imigrantu izvietošanas vietas ir koncentrētas pilsētu nomalēs, kur viniiem tiek celtas lētas, bet sociāli nodrošinātas mītnes. Tādējādi veidojas slēgtas sabiedrības daḷas (kopienas), kuras ir nodrošinātas bez nepieciešamās nodarbinātības. Tas ir savdabīgs piemērs un uzskatāms dzìves modelis imigrantu mītnes zemēs dzìvojošajiem, ka zināmu labklājỉbu ir iespējams sasniegt, neko nedarot. Veidojas deteritoriāla vide ar specifiskām vērtībām, sociālajām normām un dzīvesveidu, kurš nav raksturīgs ne jaunajā mītnes zemē, ne arī izcelsmes valstīs. Imigranti savā dzimtenē tiek uzskatīti par savdabīgu eliti, izredzētajiem un veiksminiekiem. Pētījumi liecina, ka aptuveni trešdaḷa imigrantu Francijā un puse Beḷgijā ir iebraukuši jaunajās mītnes zemēs, lai dzīvotu kopā ar radiniekiem (franču val. regroupement familial).

Pēc Eiropola rīcībā esošās informācijas viens migrants par cel̦ojumu no mìtnes zemes uz patvēruma valsti maksāja vidēji no trim līdz sešiem tūkstošiem ASV dolāru. Ekspertu aplēses liecina, ka 2015. gadā Eiropā ieradās vairāk nekā viens miljons bēglu u. Aptuveni $90 \%$ no viniiem maksāja kontrabandas organizētājiem. N̦emot vērā Eiropā 
nelikumīgi iecel̦ojušo migrantu skaitu, transnacionālo organizēto kriminālo grupējumu ienākumi tikai 2015. gadā varēja būt no trim līdz sešiem miljardiem ASV dolāru. Nelegālās migrācijas pieaugošie apjomi un atbilstošie organizēto kriminālo grupējumu ienākumi ḷāva pēdējiem iekḷūt "Kriminālās sfēras čempionu līgā". 2015. gadā vien Eiropols tika fiksējis 10700 personu, kuras turētas aizdomās par nelegālās migrācijas organizēšanu.

Eiropas Parlamentā 2015. gada 15. februārī tika apspriests jautājums, kuru ierosināja parlamenta deputāte Mara Bizoto (Mara Bizzotto), ka "Islāma valsts" (ISIS) ir iecerējusi un arī izmanto migrantu braucienus no Lībijas krasta uz "Eiropu, lai pārvērstu šo kontinentu par elli" [Priekšlikums]. To ir minējis bijušais Lỉbijas naftas un finanšu ministrs, apgalvojot, ka ISIS uzṇemas kontroli pār bēglu sūtišanu no Lïbijas, lai iefiltrētos tā saucamajos cerības braucienos. Nelegālā migrācija ir viens no būtiskākajiem faktoriem, kuri determinē terorisma draudus un to izpausmes Eiropā.

Pēc ārvalstu žurnālistu ziṇām, kuras ir publicētas izdevumā Sunday Express, 2015. gadā vairāk nekā 4000 "Islāma valsts" teroristu ir iekḷuvuši Eiropā kā bēg̣̣i (Brown, 2015). Gluži tāpat kā citiem nelegālajiem migrantiem, šo teroristu ieplūšanai ES valstīs palīdz organizētās kriminālās struktūras, kuras organizē bēgḷu nelikumīgu pārvietošanos no Ziemel̦āfrikas uz Turciju, Grieksiju un Itāliju. Palermo Prokuratūra vēl 2014. gada decembrī sāka izmeklēšanu par iespējamu ISIS teroristu maskēšanos par Lỉbijas un Sīrijas migrantiem, kas izsēdās Sicīlijas krastā. Starp nelegālajiem migrantiem, balstoties uz izlūkdienestu informāciju, Eiropā tika iepludināti no 400 līdz 600 labi sagatavotu teroristu, kuri izgāja apmācības teroristiskajā organizācijā "Islāma valsts". Eiropas valstīs ir izveidotas teroristisko grupējumu tīkla struktūras - šūniņas, kuras savā starpā nav saistītas. Grupām ir dots uzdevums darboties patstāvīgi, izvēloties uzbrukuma objektus, laiku un pañēmienus (Hinnat, Dodds, 2016).

Šo grupu identifikācijas grūtības ir saistītas ar to, ka to dalībnieki cits citu nepazīst, nezina viṇu dislokācijas vietas un komunikācijas līdzekḷus. Francijas parlamenta senatore Natālija Gulē (Nathalie Goulet) ir atzinusi, ka, ja agrāk būtu zināms, cik teroristu ir sagatavots Sīrijā un Irākā, kā arī par viṇu iekḷūšanu Eiropā, tad izdotos novērst 2016. gada 13. novembra un 2016. gada 22. marta teroristiskos aktus. Šo teroristisko aktu īstenotāju grupa bija cieši saliedēta un darbojās lielāka grupējuma ietvaros, kuras atzari ir Vācijā, Lielbritānijā, Itālijā, Dānijā, Šveicē un Turcijā. Pēdējā laikā ir mainījusies teroristisko grupējumu apmācības sistēma, stratēgija un metodika. Tiek izveidotas îpašas vienības. Mācību laiks ir garāks. Mērḳis pašreiz vairs nav nogalināt pēc iespējas vairāk cilvēku, palielināt upuru skaitu, bet gan palielināt teroristisko aktu un operāciju skaitu. Lìdz ar to pretinieks ir spiests tērēt vairāk naudas vai vairāk resursu. Arī iedzīvotāju vidū trauksmes sajūta un panika pieaug. Saistībā ar nelegālās migrācijas pieaugumu šāda veida uzbrukumu skaits varētu tikai pieaugt.

2006. gadā Latvijas Ārpolitikas institūts un Konrāda Adenauera fonds veica pētījumu par Latvijas imigrācijas politiku, tās problēmām un perspektīvām (Latvijas imigrācijas politika, 2006). Visaptverošā pētījumā tika paredzēti trīs iespējamie migrācijas 
politikas attīstības scenāriji: konservatīvais, liberālais un inkrementālais. Patlaban varētu konstatēt, ka Latvijas imigrācijas politikas īstenošanai vistuvākais bija liberālais imigrācijas attīstības modelis. ES integrācijas rezultātā tika atvērts darba tirgus, darba spēka plūsmai nekādi ierobežojumi netika paredzēti. Tomēr pētījumā formulētie ieteikumi netika pilnībā realizēti. Piemēram, ieteikums, ka "valstij daudz efektīvāk ir jāvēršas pret nelegālo uzñēmējdarbību", ir aktuāls arī pēc desmit gadiem.

2011. gadā tika izstrādāts un akceptēts pētījums "Latvijas praktiskās rīcības nelegālās migrācijas mazināšanai". Pētījuma secinājumos tika atzîts, ka "atbildīgo institūciju veikto pasākumu kopums nelegālās migrācijas mazināšanai gan pirms imigrantu ieceḷošanas, gan to ieceḷošanas un uzturēšanās laikā nodrošināja būtisku valsts iekšienē aizturēto nelegālo imigrantu skaita samazinājumu (no 310 personām 2008. gadā līdz 195 personām 2010. gadā)". Tomēr pēdējos gados atkal ir vērojams nelegālo migrantu straujš pieaugums Latvijā. Var tikai piekrist atzinumam, ka "pozitĩvu ietekmi uz Valsts robežsardzes kapacitāti valsts robežu apsardzībā atstājusi Valsts robežsardzes dalība starptautiskajās organizācijās, kā arī Eiropas Savienības projektu ietvaros iegādātās tehnikas un aprīkojuma pielietošana. Valsts robežas drošība efektīvi paaugstināta, modernizējot tehniskos līdzekḷus, kā arī paaugstinot atbildīgo personu kvalifikāciju”. L,oti būtiska nozīme nelegālās migrācijas novēršanai ir Valsts robežsardze.

Lai identificētu nelegālos imigrantus uz valsts robežas, saskaņā ar Robežsardzes likumu Valsts robežsardze veic virkni pasākumu (Robežsardzes likums):

- analizē nelegālās migrācijas risku;

- nodrošina nepārtrauktu valsts robežas uzraudzību, izmantojot tehniskos lìdzeklus un dienesta sunus;

- veic ieceļojošo personu, transportlīdzekḷu, kravu un mantu robežkontroli, izmantojot tehniskos līdzekḷus, kā arī nepieciešamības gadījumā nodrošina personu un transportlīdzekḷ pārbaudi valsts teritorijā;

- robežšḳērsošanas vietās (ostās, lidostās) veic iecel̦ojošo un izceliojošo personu profilēšanu.

Pozitīvi jāvērtē tas, ka 2015. gadā tika apstiprināts plāns “Indikatīvais rīcības plāns personu, kurām nepieciešama starptautiskā aizsardzība, pārvietošanai un uzṇemšanai Latvijā" (Indikatīvais rīcības plāns, 2015). Jāuzsver, ka tas ir izstrādāts pietiekami detalizēti un ietver sevī būtiskākos pasākumus, kā palīdzēt personām, kurām ir nepieciešama vispusīga aizsardzība. Tomēr ir vērojams mērḳtiecīgu, kompleksu, transnacionālu programmu un pasākumu trūkums nelegālās imigrācijas novēršanā un ierobežošanā, it īpaši, ja runa ir par migrantu izcelsmes valstīm. Var atzìt, ka kopumā Eiropā trūkst vienotas izpratnes un pieejas nelegālās un arī legālās migrācijas cēloṇu identifikācijā un konstruktīvas darbības to novēršanā. Šis globāla rakstura trūkums nespēj piepildīt vīzijas par drošu un labklājīgu nākotni. Valstu attīstības politiskā "labklājības valsts" modelis ir jāaizstāj ar "drošas valsts" modeli. 
Eiropas Savienībā kopumā var iezīmēt pasākumu virzienus, kuri varētu ierobežot nelegālās migrācijas apjomus:

- tiesisko aktu sankciju palielināšana par nelikumīgu robežas šḳērsošanu un nelegālās migrācijas organizēšanu;

- Eiropas Savienības ārējo robežu kontroles pastiprināšana, nodrošinot robežapsardzi (Frontex) ar nepieciešamajiem resursiem un labi sagatavotu personālsastāvu;

- vienota konsulārā un imigrācijas dienesta izveide ar kopēju datubāzi un kvalitatīvu sakaru sistēmu;

- vienota tiesisko aktu kopuma izstrāde un izveide par ārējo robežu šḳērsošanas kārtību un metodisko materiālu sagatavošanu par tiesisko aktu isstenošanas praksi;

- vienotas datubāzes un kārtības izveide iebraukšanas vīzu noformēšanā un izsniegšanā.

Eiropas Savienības politika nelegālās migrācijas ierobežošanā galvenokārt varētu būt saistīta ar kopēju piespiedu represīvo pasākumu izstrādi un realizāciju. Turklāt Eiropas valstīs būtu nepieciešama speciāla programma darbā ar imigrantiem, kas nav integrējušies sabiedrībā. Patlaban tā vēl nav Latvijas problēma, taču tas, ka imigranti neintegrējas Eiropā, var ietekmēt visu Eiropas valstu nākotni.

\section{Illegal Migration in the Context of Ensuring the Security}

\section{Abstract}

Unfavourable socio-economic situation of migrants in countries of origin causes a considerable and regular flow of migrants to the EU. Only some migrants try to become financially self-sufficient and socially integrated. Most of them try to get social protection and fully preserve national and religious identity. It may result in the growth of social tensions, conflicts between migrants and residents of countries where they receive shelter.

Uncontrolled migration leads to a breach of public order and criminal activity at the national level. It is also represents a threat to international security.

Presently, there are certain contradictions between the objective need for new workforce and the ability of socio-economic system to absorb a large number of migrants in Europe. Therefore, there is a need for a regular prognostication of migration risks and the development of methods, which will enable the migration management. Legal and institutional support for migration policies in Europe does not provide a prompt 
and effective migration management. Which emphasises the necessity of their improvement, especially taking into account the fact that Europe needs migrants to cope with the shortage of manpower and correct the demographic situation in general.

Keywords: globalization, illegal migration, migration, security.

\section{Literatūra un avoti}

1. Brown, Aaron. "Just wait..." Islamic State reveals it has smuggled thousands of extremists into Europe. 18.11.2015. Iegūts no: http://www.express.co.uk/news/world/555434// Islamic-State-ISIS-Smuggler-THOUSANDS-Extremists-into-Europe-Refugees

2. Apvienoto Nāciju Organizācijas Konvencija pret transnacionālo organizēto noziedzību. Pieñemts 15.11.2000. Starptautisks dokuments. Latvijas Vēstnesis, 87(2474), 06.06.2001. Iegūts no: http://likumi.lv/doc.php?id=25089

3. Cilvēka drošumspēja un NAP2020. Pārresoru koordinācijas centrs. Iegūts no: http://www.pkc. gov.lv/cilv\%C4\%93ka-dro\%C5\%A1umsp\%C4\%93ja-un-nap2020

4. Connor, P., Cohn, D'V., Gonzalez-Barrera, A. Changing Patterns of Global Migration and Remittances. Iegūts no: http://www.pewsocialtrends.org/2013/12/17/changing-patternsof-global-migration-and-remittances/

5. Hansen, R. Globalization, Embedded Realism, and Path Dependence The Other Immigrants to Europe. Comparative Political Studies, 2002, p. 583.

6. Hinnat, L., Dodds, P. IS trains 400 fighters to attack Europe in wave of bloodshed. AP News, 24.03.2016. Iegūts no: http://bigstory.ap.org/article/1c1661cef71c4a1a93f3a1863d27a284/ trains -400

7. Desilver, D. How the U.S. compares with other countries taking in refugees. PewResearchCenter, 24.09.2015. Iegūts no: http://www.pewresearch.org/fact-tank/2015/09/24// how-the-u-s-compares-with-other-countries-taking-in-refugees/

8. Ilmārs Latkovskis: migrācija ir daudz draudošāka problēma, nekā iepriekš esam apjautuši. Latvijas Republikas Saeima. Aktualitātes, 13.01.2016. Iegūts no: http://www.saeima.lv/lv/ aktualitates/saeimas-zinas/24280-ilmars-latkovskis-migracija-ir-daudz-draudosaka-problema-neka-ieprieks-esam-apjautusi

9. Indikatīvais rīcības plāns personu, kurām nepieciešama starptautiskā aizsardzība, pārvietošanai un uzṇemšanai Latvijā. Latvijas Republikas Iekšlietu ministrija, 29.09.2015. Iegūts no: http://www.iem.gov.lv/lat/patveruma_mekletaji_es_un_latvija/?doc=30 IS trains 400 fighters to attack Europe in wave of bloodshedIS trains 400 fighters to attack Europe in wave of bloodshed//http://bigstory.ap.org/article/1c1661cef71c4a1a93f3a1863 d27a284/trains-400-fighters-attack-europe-wave-bloodshed530http://www.iem.gov.lv/lat/ patveruma_mekletaji_es_un_latvija/?doc=30

10. Ivars Brīvers: Ekonomikas izaugsme nenozīmē labklājỉbas pieaugumu. Neatkarīgā, 17.03.2016. Iegūts no: http://nra.lv/latvija/166769-ivars-brivers-ekonomikas-izaugsme-nenozimelabklajibas-pieaugumu.htm

11. Latvijas imigräcijas politika: Problèmas un perspektìvas. Rīga: Latvijas Ārpolitikas institūts, 2006. 
12. Latvijas praktiskā rīcība nelegālās migrācijas mazināšanai: [Pētỉjums]. Rīga: Eiropas migrācijas tīkls, 2011. Iegūts no: http://ec.europa.eu/dgs/home-affairs/what-we-do/ networks/european_migration_network/reports/docs/emn-studies/irregular-migration/ lv_20120216_migracijasmazinasanai_lv_version_final_lv.pdf

13. Migration and migrant population statistics. Eurostat. 2015. URL. Iegūts no: www.ec.europa. eu/eurostat/statisticsexplaine d/index.php/Migration_and_migrant_population_statistics.

14. Migration Reports. EU Neighbourhood Migration Report 2013. Migration Policy Centre. Iegüts no: http://www.migrationpolicycentre.eu/publications/migration-report/

15. Nedelkovski, M. Kakvo donasjat Rotshildovi v ES: "90\% ot migrante ot Azija sa mladi mjze" Tjaxnata dostavka v ES se finansira ot organizaciite na Rotshildovi. 05.09.2015. (Неделковски, М. Какво Аонасят Ротшилдови в ЕС: “90\% от мигрантите от Азия са млаАи мъже” - Тяхната доставка в ЕС се финансира от организациите на Ротшицдови.). Iegūts no: www.zahariada.com/какво-Аонасят-ротшилдови-в-ес-90

16. Priekšlikums Eiropas Parlamenta rezolūcijai par teroristu iepludināšanu Itālijā, izmantojot slepeno imigrāciju. Eiropas Parlaments. Iegūts no: http://www.europarl.europa.eu/sides/ getDoc.do?pubRef=-//EP//TEXT+MOTION+B8-2015-0189+0+DOC+XML+V0//LV

17. Robežsardzes likums. Pieñemts 27.11.97. Likums. Iegüts no: http://likumi.lv/doc.php?id=46228

18. Rukovodstvo po pazrabotke effektivnoj politiki v oblasti trudovoj migraciji v stranax proisxozhdenija i naznacenija. (Руководство по разработке эффективной политики в области трудовой миграции в странах происхожАения и назначения.). OSCE, 23.05.2006. Iegūts no: http://www.osce.org/ru/eea/19243 